\title{
Collecting in Central Asia and the Caucasus: U.S. National Plant Germplasm System Plant Explorations
}

\author{
Barbara C. Hellier ${ }^{1,2}$ \\ USDA, ARS, Western Regional Plant Introduction Station, Washington State University, \\ 59 Johnson Hall, Pullman, WA 99164-6402
}

Additional index words. plant genetic resources, Taraxacum kok-saghyz, wild crop relatives

\begin{abstract}
The USDA-ARS National Plant Germplasm System is charged with the preservation of economically important crop plants and their wild relatives. Curators in the System strive to develop collections capturing the genetic diversity of each species. One mechanism for filling gaps in collections is through plant exploration. The USDAARS National Germplasm Resources Laboratory, Plant Exchange Office administers funding and coordinates plant explorations for the System. In the past decade, there have been 38 collecting missions in Central Asia and the Caucasus. This area is rich in plant biodiversity and is a center of diversity for many crop species and their wild relatives. The author has had the opportunity to participate in four explorations in the area focusing on wild crop relatives. This included a trip to Kazakhstan targeting Russian dandelion, Taraxacum kok-saghyz L.E. Rodin, a source of natural rubber. In this mission, a total of 22 accessions of $T$. kok-saghyz and six accessions of other Taraxacum species were collected.
\end{abstract}

The USDA-ARS National Plant Germplasm System (NPGS) is a collection of public and private organizations dedicated to preserving genetic diversity of economically important plant species. Accessions in the NPGS are distributed free of charge and without restrictions to researchers around the world (Bretting, 2007). System curators strive to develop collections that capture the genetic diversity of crop plants and their wild relatives. One of the basic activities of NPGS curators is acquisition of new material to fill gaps in their collections, accomplished through exchange with other genebanks or individuals or through exploration. Funding and coordination of exchanges and explorations to fill gaps in the NPGS collections are provided by the National Germplasm Resources Laboratory, Plant Exchange Office (PEO) (Williams, 2005). Proposals for plant explorations are accepted yearly following PEO established guidelines. For foreign explorations, the PEO obtains prior informed consent from the national authority in the host country and negotiates benefit sharing as directed by the Convention on Biological Diversity. Benefit sharing is designed to support conservation of plant genetic resources in the host county.

A typical NPGS foreign plant exploration has two U.S. scientist participants and two host country cooperators, usually from the country's plant genetic resources program. Trips are 10 days to 3 weeks long and all expenses are usually paid by the USDA-ARS. Germplasm collections are documented with complete passport data [latitude/longitude (including

Received for publication 22 Mar. 2011. Accepted for publication 9 June 2011.

This paper was part of the workshop "Horticultural Value of Wild Genetic Resources" held 3 Aug. 2010 at the ASHS Conference, Palm Desert, CA, and sponsored by the Genetics and Germplasm (GG) Working Group.

${ }^{1}$ Horticulture crops curator.

${ }^{2}$ To whom reprint requests should be addressed; e-mail barbara.hellier@ars.usda.gov. datum), habitat description, site directions, and accession description], herbarium voucher specimens, and images of the material collected and sites. The collected germplasm is shared with the host country.

Over the past decade, the PEO has supported 38 plant explorations to Central Asia and the Caucasus. There are two major reasons for the extensive activity in this region. One reason is that with the emergence of independent nations that split from the Soviet Union when it dissolved in 1991, the area became accessible to U.S. scientists. The other, and more important, reason is that this region is rich in plant biodiversity. Conservation International recognizes two major biodiversity hotspots (areas under threat of destruction) in Central Asia and the Caucasus. One is in the area encompassing the Republic of Georgia, Azerbaijan, and parts of Armenia. The other is in the Pamir and Tien Shen mountains (Conservation International, 2007). These areas include centers of diversity for several crop plants and their wild relatives: apple, pear, pistachio, apricot (secondary center), onion, garlic, spinach, carrot, wheat, peas, lentils, chickpea, and flax (Zohary, 1970). PEO explorations have targeted this diversity for collection and preservation (Table 1).

A specific example of a NPGS-sponsored plant exploration in Central Asia is the 2008 mission to collect Russian dandelion, Taraxacum kok-saghyz L.E. Rodin, in Kazakhstan. Before the exploration, there were six accessions identified as T. kok-saghyz in the NPGS; four were not viable, and for two, the taxonomy was questionable. T. kok-saghyz is of interest to scientists in the United States and around the world as a source of natural rubber from a temperate plant. T. kok-saghyz is native to southeastern Kazakhstan in the area of the Kegen and Tekes rivers. This mission was undertaken in July 2008 with two U.S. participants, the author and Dr. Maureen Whalen, USDA-ARS; two participants from Kazakhstan, Dr. Roman Jashenko, President of Tethys Scientific Society, Institute of Zoology, Almaty, Kazakhstan (organizer) and Dr Anna
Ivachsenko, botanist; and Mr. Sergey Shuvalov from the N.I. Vavilov Research Institute of Plant Industry, Russia. Benefit sharing with Kazakhstan included participation of scientists from the Kazakh Scientific Production Center of Farming and Plant Growing in training programs for genebank management and the English language organized by the International Center for Agricultural Research in the Dry Areas (Edward Garvey, personal communication). Of the 40 sites that were surveyed/explored, 22 were found to have T. kok-saghyz. Both root pieces and seed were collected. Root pieces were only collected from populations with abundant plant numbers. Collections were limited to plants exhibiting classical T. kok-saghyz morphology: gray-green leaf color, entire to undulate leaf margins, the presence of rubber strings from broken root, and the presence of horned bracts (Rodin, 1933), to decrease the chance of collecting hybrids (Koroleva, 1940). The habitat where T. kok-saghyz was found was a meadow to meadow-steppe transition zone with sandy to loam soil. These sites were close to water but were not wet and were usually heavily grazed. The presence of grazers did not seem to affect plant numbers or seedling establishment but did affect the presence of seed for collection!

The collected seed and root pieces were divided between the U.S. and Russian participants. The cooperating institution in Kazakhstan declined accepting the material for conservation ex situ. The U.S. portion of the seed and root pieces was brought back to the Western Regional Plant Introduction Station in Pullman, WA. Both were planted in the field in Pullman for seed increase. On flowering, accessions were caged with honeybees introduced as pollinators. The generated seed was harvested and is available for distribution through the NPGS database, Germplasm Resources Information Network (GRIN) at $<$ http://www.ars-grin/npgs $>$. The surviving plants will be used for collecting morphologic characterization data and determining rubber and inulin content. 
Table 1. Summary of National Plant Germplasm System supported plant explorations in Central Asia and the Caucasus from 2001 to 2010.

\begin{tabular}{|c|c|c|c|c|c|c|c|c|}
\hline \multirow[b]{2}{*}{ Country } & $2001-2003$ & 2004 & 2005 & 2006 & 2007 & 2008 & 2009 & 2010 \\
\hline & \multicolumn{8}{|c|}{ Targeted Crop Group, Genus, or Species } \\
\hline Armenia & $\begin{array}{l}\text { Forage } \\
\text { legumes; } \\
\text { fruits, } \\
\text { nuts, and } \\
\text { woody } \\
\text { landscape } \\
\text { plants }\end{array}$ & $\begin{array}{l}\text { Food and forage } \\
\text { legumes }\end{array}$ & $\begin{array}{l}\text { Cereals, food } \\
\text { and forage } \\
\text { legumes }\end{array}$ & Fruits and nuts ${ }^{\mathrm{y}}$ & & & $\begin{array}{l}\text { Forage } \\
\text { legumes; } \\
\text { wild } \\
\text { Lactuca }\end{array}$ & \\
\hline Azerbaijan & & $\begin{array}{l}\text { Food and forage } \\
\text { legumes }\end{array}$ & & $\begin{array}{l}\text { Woody landscape } \\
\text { plants }\end{array}$ & Fruits and nuts & $\begin{array}{l}\text { Woody } \\
\text { landscape } \\
\text { plants, fruits } \\
\text { and nuts }\end{array}$ & $\begin{array}{l}\text { Fruits and } \\
\text { nuts }^{\mathrm{y}}\end{array}$ & \\
\hline Kazakhstan & $\begin{array}{l}\text { Wheat } \\
\text { and } \\
\text { barley }\end{array}$ & Wheat and barley & & & & $\begin{array}{l}\text { Russian } \\
\text { dandelion }{ }^{z}\end{array}$ & & \\
\hline Kyrgyzstan & & & & $\begin{array}{l}\text { Forage and } \\
\text { turfgrasses }\end{array}$ & & & $\begin{array}{l}\text { Fruits and } \\
\text { nuts }\end{array}$ & \\
\hline $\begin{array}{l}\text { Republic of } \\
\text { Georgia }\end{array}$ & $\begin{array}{l}\text { Wild } \\
\text { spinach }\end{array}$ & $\begin{array}{l}\text { Forage and food } \\
\text { legumes; clover; } \\
\text { fruits, nuts, and } \\
\text { woody landscape } \\
\text { plants }\end{array}$ & $\begin{array}{l}\text { Herbaceous } \\
\text { ornamentals }\end{array}$ & Fruits and nuts ${ }^{\mathrm{y}}$ & $\begin{array}{l}\text { Medicinal plants } ; \\
\text { woody landscape } \\
\text { plants; vegetables }\end{array}$ & $\begin{array}{l}\text { Woody } \\
\text { landscape } \\
\text { plants }\end{array}$ & $\begin{array}{l}\text { Forage } \\
\text { legumes; } \\
\text { wild } \\
\text { Lactuca }\end{array}$ & $\begin{array}{l}\text { Fruits and } \\
\text { nuts; } \\
\text { wheat }\end{array}$ \\
\hline Tajikistan & $\begin{array}{l}\text { Cereals, } \\
\text { forage } \\
\text { and food } \\
\text { legumes, } \\
\text { and } \\
\text { grasses }\end{array}$ & $\begin{array}{l}\text { Food and forage } \\
\text { legumes and } \\
\text { wheat }\end{array}$ & & $\begin{array}{l}\text { Cereals, legumes, } \\
\text { and wild } \text { Allium }^{z}\end{array}$ & & & & \\
\hline Turkmenistan & $\begin{array}{l}\text { Wild } \\
\text { Allium; } \\
\text { forage } \\
\text { legumes }\end{array}$ & & & & & Melons & & \\
\hline Uzbekistan & Forages & $\begin{array}{l}\text { Wild garlic } \\
\text { and carrot }{ }^{z}\end{array}$ & & & & & & \\
\hline
\end{tabular}

${ }^{\mathrm{z}}$ Collection mission in which the author participated.

${ }^{y}$ Explorations that visited two countries.

Source: K. Williams, Plant Exchange Office, National Germplasm Resources Laboratory.

\section{Literature Cited}

Bretting, P.K. 2007. The US National Plant Germplasm System in an era of shifting international norms for germplasm exchange. Acta Hort 760: $50-60$.

Conservation International. 2007. Center for Applied Biodiversity Science. Biodiversity hotspots. 29 July 2010. <http://www.biodiversityhotspots.org/ Pages/default.aspx $>$.
Koroleva, V.A. 1940. The biological peculiarities of Kok-saghyz and of the non-rubber-bearing dandelions infesting Kok-saghyz plantations. USDA, Agriculture Research Administration, Bureau of Plant Industry, Soils and Agriculture Engineering Rubber Plant investigation.

Rodin, L.E. 1933. Taxonomic description of Taraxacum kok-saghyz. US Dept. of Agr. Bureau of Plant Industry. No. 43 Emergency Rubber Project Report. V.1.
Williams, K.A. 2005 An overview of the US National Plant Germplasm System's Exploration Program. HortScience 40:297301.

Zohary, D. 1970. Centres of diversity and centers of origin, p. 33-42. In: Frankel, H.O. and E. Bennett (eds.). Genetic resources in plants: Their exploration and conservation. FAO, International Biological Programme, distributed by Blackwell Scientific, Oxford. 